\title{
Strategy of Xi'an International Land Port and Regional Economic Development
}

\author{
Congli Xie $\mathrm{Xi}^{1, \mathrm{a}}$ \\ ${ }^{1}$ Bussiness School , Xi'an International University, Xi'an,710077, China \\ email:54471753@qq.com
}

\begin{abstract}
Keywords: Xi'an international land port ; Economic and trade ; industry transfer ; resources integration;
\end{abstract}

\begin{abstract}
With the continuous advance of China's export-oriented economy, Xi'an international land port plays an important role in deeping the logistics resource integration, logistics industry aggregation,as well as the undertaking of the industrial transfer in Northwest region.This paper, starting from the current state of Xi'an land port, introduced the three supporting platform: Xi'an comprehensive Bonded Zone, Xi'an railway container center station, Xi'an Highway Harbor, and analysised the important influence of dry ports in promoting industrial transfer, regional trade and economic development in Shaanxi and other important influence,finally put forward suggestions for improvement of existing problems.
\end{abstract}

\section{Introduction}

With the continuous improvement of China's foreign trade and rising demand of inland trade, coastal ports, with facing to the limited radiation and fiercely competitions and in order to develop their business and enhance the competitiveness ,they have to construct dry ports in the inland region to develop their competitiveness[1], and it has become a necessary trend. In the past few years, China has formed a number of inland port group, including northeast China inland port group headed by Dalian, eastern provinces within 12 inland port group headed by Tianjin and, inland Harbors headed by Shanghai and Zhejiang[2].In 2008, as the first domestic international dry port,Xi'an International Port attracted many coastal ports , many coastal ports have cooperated with Xi'an port including Tianjin Port, Shanghai, Dalian, Qingdao etc. By establishing its own independent port service area in Xi'an port zone. Xi'an international land port has not only becoming an important nexus between Northwest and coastal, and becoming an important power in driving the rapid development of the Northwest Northwest import and export business and their economy.

\section{Introduction to the international land port}

\section{Concept and function of the international land port}

- Xi Ping, as "Father of the dry port", believes that international inland port is a international port,constructed at the railway intersection and highway line area of economic center, according to the relevant state laws and regulations, which has the function of opening to the outside world and provides trade and modern logistic,and provides international port services and port services platform for the economic development of inland areas. Its main features include: Container management functions, container cargo storage, container loading and unloading and other services[3].

- Freight Forwarding function: Undertaking various transport operations, services for domestic and overseas transportation business through shipping, aviation and other transport companies on behalf of the commission, receiving or sending goods and furnishing the issuance of bills of lading, container leasing and management, providing customs agents and multimode transport services.

- Port Function: Settig up customs animal and plant quarantine, commodity inspection, health inspection and other regulatory authorities in inland areas, providing customers with customs 
clearance of goods and services.

- Third party logistics service functions: fully playing the advantages in the collection of goods transportation, warehousing, packaging, information classification, providing customers with international logistics services. Helping enterprises to manage and restructure the supply chain.

- Information processing and service function: receiving, transmitting and processing container, vehicle, documents and other information, and in a timely manner to provide the information service for the customer.

- Other services: inspecting ,cleaning and maintenance the vehicles, loading and unloading machinery, settling for insurance services for customer.

\section{Characteristics of international land port}

- Located in inland areas without coastal: international land ports are often built in inland without sea area, and general port are constructed in the coastal areas or along the river, the biggest difference between international land port and general port is that international land port locates inland,therefore they have no ship loading and unloading operations

- Handling the import and export declaration formalities: One of the main functions of the international land ports is can handling customs clearance formalities in the inland areas, it helps companies to save import and export customs clearance time and improve the efficiency of good flow, to reduce operating costs, while greatly enhance the international importance of land ports in international trade, and it is conducive to the rapid development of international land ports. Before the establishment of an inland port, import and export goods inland must be to coastal ports and have to go through all kinds of customs procedures, which is cumbersome and time-consuming, and greatly prolonging the time of customs clearance of goods, and not conducive to the development of international trade. Therefore the international land port appears a good solution to the difficult problem of inland enterprises declaration.

- Extension of the harbor operation in the inland: another important function of the international port is to provide port services for the inland areas, which is the same as the functions of the coastal ports,so it is an extension of the coastal ports in the inland areas. International land port is a platform to provide the container freight, cargo loading and unloading, goods storage, cargo clearance procedures and other services for the owner[4].

\section{General situation of Xi'an international land port}

\section{- Profile of Xi'an international land port}

Xi'an international port covers an area of 44.6 square kilometers, and has obvious advantages in the western region because of convenient traffic conditions.It has a good ecological environment, Chan Ba wetland protection area around the site of World Horticultural Exposition, and it includes three supporting platforms: Xi'an railway container center station, Xi'an comprehensive Bonded Zone and Xi'an Highway port. Xi'an international port has built a 60 billion industry group, namely: international land port, port economy, energy and chemical trade, modern logistics, fashion life service industry, domestic trade; Eight functional areas: container loading and unloading zone, free trade zone, the domestic trade area, comprehensive service area, living area, emergency logistics park, industrial transfer zone, urban and rural construction area; Six functions of spindle: high-speed beltway, three ring road, Xi Yu highway, planning airport highway connecting line, Cao Lin Lu, Fangwei Road, Harbor Road. As the first international land port in China,Xi'an international port has a huge boost to the economy of Shaanxi and the northwest region.

\section{- Xi'an Comprehensive Bonded Zone}

Xi'an Comprehensive Bonded Zone approved construction in 2011. As the first comprehensive free trade zone in the northwest, Xi'an comprehensive bonded zone and Xi'an railway container center station, Xi'an highway Port are complementary to each other, they played a fully functional overlay, formed a relatively complete port service functions, and achieve the effective extension of coastal port service function. It becomes an important platform for Xi'an Comprehensive Bonded Zone to attract investment for the development of export-oriented economy and industry transfer 
to Shaanxi and Xi'an by dealing with clearance business in the mainland. Xi'an comprehensive bonded area has an open region for bonded logistics, warehousing, processing, also monitoringand checking the cargoes of import and export. In addition, Xi'an comprehensive bonded zone is also responsible for display of goods, the formation of a multi-functional economic region. Besides that, it also has a lot of preferential policies and strong ability to open to the outside world. And it has laid a solid foundation for the development of the Xi'an international port[5].

\section{- Xi'an Railway Container Central Station}

Xi'an container center station is one of the only 18 railway container center station of China with four functional regions:a container handling zone, express operation area, special cargo working areas in the shipment, the goods vehicle operation area. Establishment of an independent customs supervision enclosed spaces and cargo inspection and quarantine fumigation area inside the station. Xi'an international land port truly realizes "port after the shift, documents local handling, sea-railway transport, , seamless"to provide security for reliable infrastructure, which provides a solid foundation for import and export goods clearance and quick release.Xi'an Railway Container Center Station is the Northwest's largest facilities and most comprehensive railway container transportation center, having two of the largest container loading and unloading lines, effective length 850 meters, door hanging Traveling rail length of 808 meters, four 40 tons rail container gantry crane installations, and 2 container trucks and 2 car batteries.

\section{- Xi'an Highway Port}

Xi'an highway port is an integrated logistics and transportation hub with international logistics, transportation, logistics information exchange, leisure and rest. Based on Xi'an comprehensive free trade zone and Xi'an railway container center station,Xi'an highway port focusing on highway transportation and port information trading services to serve the logistics and trade throughout the northwest inland areas. The purpose of Xi'an highway port is to ffer the advantages of regional traffic resources, reflecting the logistics characteristics of high efficiency of road transport, integrated transport, information management, forming a platform with integrated transport, multimode transport, information, finance, trade, exhibition, science, education, research and development and other functions. Rely on their own advantages, the integration of transport resources in the northwest region, Xi'an highway port has achieved to expand the scope of the port services and enhance the Xi'an port service capacity.

\section{Influence of Xi'an international land port on regional economy}

\section{Promote the industrial transfer in the northwest region}

Compared with the coastal economy, the economic development of the northwest region is slow. To speed up economic development and further implement the strategic objectives of the national development of the western region, Shaanxi must develop foreign industries. It is an important measure to undertake industrial transfer and break the low degree of Shaanxi's open economy. In the process of Shaanxi Province actively undertaking international industrial transferring, Xi'an international land port built an international industrial transfer platform in the northwest of China, which enhances the northwest area resource set cohesion, industrial support, so as to enhance the Shaanxi Province logistics trade efficiency and service level, improve the investment environment of the northwest area, expand the northwest inland areas of market economy and international docking. Xi'an comprehensive bonded zone as a comprehensive strategic resources, is superior in Shaanxi Province to undertake international industrial transfer and it has a superior policy, foreign goods into the area implement free trade and domestic goods into the area are deemed exports, the trading of goods between the enterprises in the zone does not levy value-added tax and consumption tax, these policies promote the foreign enterprises invest in the northwest, and they are becoming the main advantage for Shaanxi Province to undertake international industrial transfer[6]. 


\section{Promote the development of the Northwest Trade Economy}

Xi'an international land port provides a regional cooperation platform for the development of logistics industry in the northwest region. In the past, Shaanxi import and export commodities are generally required by the coastal ports to handle customs clearance in handling, storage, shipping and import and export with tedious customs procedures, long time, high cost. After the Xi'an international land port construction, the function of the multimode transport infrastructure and port services, have greatly enhanced international trade service level of Shaanxi and the northwest of China, greatly reduced the transit link of import and export goods in the northwest, reduced the enterprise cost, saves the time of the import and export of goods, improved enterprise efficiency. At present, Xi'an International Port District, helps Shaanxi establish cooperative relations with Tianjin , Qingdao, Lianyungang, Shanghai , the Gansu ,which promote the development of the local economy greatly.

\section{Promote the development of Trading Area of Xi'an international land port}

Xi'an International Port District, has played a huge industry gathering after its completion, the real estate industry and the hotel are also developed rapidly. Trading Area of Xi'an international land port will be the tenth largest district in Xi'an. With its high speed and deep development ,Xi'an International Port District will also form a set of dining, shopping, entertainment and leisure as one of the commercial system, and gradually become the characteristics of the gold commercial circle. Xi'an International Port District has become a hot spot for many business enterprises investment, such as Maersk, FedEx, Walt-Mart, ProLogis and China Mobile, Lenovo Group, Geely Group etc. , entering into the zone.

\section{Problems existing in the development of $\mathrm{Xi}$ 'an international land port}

\section{Immature development model and management system}

As an emerging industry and the first international inland port, Xi'an international land port has no experience to draw on, so the development mode and management system of Xi'an land ports of is still imperfect and is still in continuous exploration, the current inland ports operations and management are more reference to harbor operations management methods, but in terms of international land transport legislation, regulations, etc., still blank, these become bottlenecks of the international development of land port and it must be solve.

\section{Slow integration of logistics resources}

Xi'an international land port has integrated with coastal ports, railway transportation, port management, finance and insurance, logistics, information services and other logistics organization, but the integration progress is slow, which is serious affecting the operations and development. Besides, the integration ability to the scattered surrounding logistics resources areas is not enough for Xi'an international land port, therefore it can not provide a comprehensive logistics service to the surrounding logistics enterprise.

\section{Suggestions for the development of Xi'an international land port}

\section{Improve the system and laws of land port}

Xi'an international land port needs to joint research centers, with reference to the marine transportation, air transportation laws, regulations, rules, practices and management system, and organize professional personnel to research the development mode according to the current situation of Xi'an international land port, set the development goal, clear the development direction and formulate the management system of Xi'an International Port. These will lead Xi'an international port to develop better.

\section{Accelerate the integration of logistics resources}

Xi'an international land port should accelerate the resource integration of Port Industrial Zone, the coastal ports, railway container center station, railway freight yard, logistics park, logistics enterprises, finance, insurance, information service etc. Increasing the role of Xi'an international 
land port in Shaanxi logistics industry and local logistics enterprise.

Strengthen cooperation with neighboring cities

Xi'an international land port should increase its business scope, by integrating logistics resources in the surrounding area of Xi'an, and then promoting the import and export trade business and logistics development in the urban surrounding areas, driving the developing speed of the logistics trade in local area, and then as Shaanxi for the center to the nationwide diffusion, to strive to build Xi'an International Port Zone with Shaanxi characteristics.

\section{Acknowledgment}

In this paper, the research was sponsored by Social Science Fund Project of Shaanxi Province (Project No. 2015D060) and Shaanxi Provincial Department of Education Science Research Project (Project No. 2016JK2158).

\section{References}

[1] Tanlai che, Development profile of China's "land port" , the view of the mainland bridge, in July 2010.

[2] Jing Zhang, prevalence of inland port construction in the Midwest City, Land bridge Horizon, Augus.2012.

[3] Zhao Li , Construction of Xi'an international land port boost regional opening,Land bridge Horizon,, January 2011 .

[4Zhi Zhang, Interaction between port and international land port, Land bridge Horizon, January 2011 .

[5] Xiaoan Qiang , Exploration and Thinking of Xi'an international land port construction Chinese Economic Herald, 2011(1).

[6] Junjing Zhao, Xi'an International Port District: the leader of the construction of the mainland,Land bridge Horizon, November 2013. 